\title{
Consumer Behaviour Regarding Performance of LIC Housing Finance Ltd.
}

\author{
Lakhwinderjeet Kaur \\ (Head, Department of Commerce and Management, Guru Hargobind Sahib Khalsa Girls' College, Karhali \\ Sahib, Patiala, India.)
}

\begin{abstract}
The Life Insurance Corporation (LIC) was incorporated in India in 1956 by nationalization of private insurance companies functioning in the country. LIC is statutorily required to invest 25 per cent of its annual accretion of its controlled funds in socially oriented schemes including housing in addition to subscribing to the bonds/debentures floated by State Housing Boards, HUDCO, etc. LIC has been granting loans right from its inception. With the announcement of National Housing Policy in 1987 and the subsequent setting up of National Housing Bank, LIC set up LIC Housing Finance Limited (LICHFL) on 19th July, 1989 under the Companies Act, 1956. The company went public in the year 1994. The company is the second largest housing finance company in the country after HDFC. Almost 93 per cent of the company's loans are to retail customers and the balance 7 per cent to project developers. In the present paper, a survey of 100 respondents has been conducted to examine and compare their opinion regarding the functioning of LIC Housing Finance Ltd. in Bathinda. An attempt has been made to examine the extent to which LIC Housing Finance Ltd. has catered to the needs of the people.
\end{abstract}

Keywords: Housing Finance, LICHFL, Performance, Chi-square, Loans.

\section{INTRODUCTION}

LIC Housing Finance Limited (LICHFL) was set up by LIC on 19th July, 1989 under the Companies Act, 1956. The main objectives for the setting up of LICHFL were to assist individuals by providing finance for construction/ purchase of residential house or flat, to assist individuals by providing finance for extension/renovation of residential units, to provide loans to co-operative societies and housing boards for residential housing projects, etc. The company went public in the year 1994. It is the second largest housing finance company in the country after HDFC. The Company possesses an extensive marketing network in India. It has its Registered and Corporate Office in Mumbai and has 7 Regional Offices, 13 Back Offices and 188 marketing offices and 1 customer service point across India as on $31^{\text {st }}$ March, 2012. The Company received the 'AAA' credit rating from CRISIL for the 11th consecutive year in 2011-12, indicating the highest level of safety. [1]

\section{Objectives Of The Study}

The main objectives of the study are:

a) To asses the consumer behavior regarding performance of LICHFL.

b) To conclude in the basis of the study and provide suggestions thereof.

\section{Research Methodolgy}

The study is based on primary data that has been calculated by conducting a questionnaire survey of 100 respondents in Bathinda district. The data has been analysed by using percentages, weighted average scores and chi square test. Income- wise, the respondents have been divided into four groups on the basis of their annual family income, viz. Below Rs. 1.5 lakhs (I-1), Rs. 1.5 lakhs but below Rs. 3 lakhs (I-2), Rs. 3 lakhs but below Rs. 6 lakhs (I-3) and Above Rs. 6 lakhs (I-4). Age-wise, the respondents have been classified into four categories, viz. A-1(Below 30 years), A-2 (30 years to 45 years), A-3 (45 years to 60 years) and A-4 (Above 60 years) .

\section{Analysis And Interpretation}

The study analyses the opinion of the respondents regarding various aspects of the functioning of the company such as source of information, awareness of the name of scheme under which the loan is taken, adequacy of loan, purpose of loan, tenure of loan, amount of loan, repayment schedule, rate of interest, etc. 


\subsection{SOURCE OF INFORMATION ABOUT LICHFL LTD.}

There are many sources from where a person comes to know about a particular company. The respondents were asked about the source of information from where they have come to know about LICHFL Ltd. Table 1 shows the income wise distribution of respondents regarding source of information about LICHFL.

Table 1 Source of Information about LICHFL Ltd.

(Income-wise Distribution of Respondents)

\begin{tabular}{|c|c|c|c|c|c|}
\hline Source & I-1 & I-2 & I-3 & I-4 & TOTAL \\
\hline Newspaper, TV etc. & $8(19.51)$ & $5(14.71)$ & $3(18.75)$ & $0(0.00)$ & 16 \\
\hline Friends/Relatives & $8(19.51)$ & $9(26.47)$ & $0(0.00)$ & $0(0.00)$ & 17 \\
\hline Employees & $7(17.07)$ & $10(29.41)$ & $2(12.50)$ & $1(11.11)$ & 20 \\
\hline Direct Selling Agents & $18(43.91)$ & $10(29.41)$ & $11(68.75)$ & $8(88.89)$ & 47 \\
\hline N & $41(100)$ & $34(100)$ & $6(100)$ & $9(100)$ & 100 \\
\hline
\end{tabular}

Chi-square value $=17.86$, d.f. $=9$, Significant at 5 per cent level of significance

Income-wise, table 1 reveals that majority of the respondents from category I-4 (88.89 per cent) and I-3 (68.75 per cent) and a large number of respondents from I-1 (43.91 per cent) have got the information through 'direct selling agents' whereas, 29.41 per cent of the respondents from category I-2 have 'employees' as the source of information. The Chi-square value (17.86) is more than the table value (16.9) that indicates that significant differences exist among different income categories as regards the source of information.

Table 2 Source of Information about LICHFL Ltd.

(Age-wise Distribution of Respondents)

\begin{tabular}{|c|c|c|c|c|c|}
\hline Source & A-1 & A-2 & A-3 & A-4 & TOTAL \\
\hline Newspaper, TV etc. & $6(21.43)$ & $9(24.32)$ & $1(3.85)$ & $0(0.0)$ & 16 \\
\hline Friends/Relatives & $10(35.71)$ & $7(18.92)$ & $0(0.00)$ & $0(0.00)$ & 17 \\
\hline Employees & $9(32.14)$ & $7(18.92)$ & $3(11.54)$ & $1(11.11)$ & 20 \\
\hline Direct Selling Agents & $3(10.72)$ & $14(37.84)$ & $22(84.62)$ & $8(88.89)$ & 47 \\
\hline $\mathrm{N}$ & $28(100)$ & $37(100)$ & $26(100)$ & $9(100)$ & 100 \\
\hline
\end{tabular}

Chi-square value $=40.82$, d.f. $=9$, Significant at 1 per cent level of significance

Age-wise, table 2 depicts that majority of the respondents (88.89 per cent) from category A-4, 84.61 per cent from category A-3 and 37.84 per cent from category A-2 have got information through 'direct selling agents' whereas 35.71 per cent from category A-1 have come to know about the institution through 'friends/relatives'. The Chi-square value (40.82) shows that significant differences exist among different age categories regarding the source of information about the institution.

\subsection{Awareness about the Scheme under Which Loan Is Taken}

The Housing Finance Companies provide loans under various schemes. Similarly LICHFL provides loans under various schemes namely Griha Prakash, Griha Shobha, etc. When the customers were asked regarding the awareness about the scheme, 80 per cent of the respondents knew about the scheme and 20 per cent did not know the scheme under which they have taken loan.

\subsection{Purpose of Loan}

Housing Finance Companies provide loans for various purposes as for purchase of house, construction, extension, repairs, etc. Tables 3 and 4 present the income-wise and age-wise distribution of the respondents regarding the purpose of the loan respectively.

Table 3 Purpose of Loan (Income-wise Distribution of Respondents)

\begin{tabular}{|c|c|c|c|c|c|}
\hline Purpose & I-1 & I-2 & I-3 & I-4 & TOTAL \\
\hline Purchase of Plot & $6(14.64)$ & $13(38.24)$ & $0(0.00)$ & $0(0.00)$ & 19 \\
\hline Purchase of House & $19(46.34)$ & $4(11.76)$ & $2(12.50)$ & $1(11.11)$ & 26 \\
\hline Construction & $3(7.32)$ & $4(11.76)$ & $12(75.00)$ & $8(88.89)$ & 27 \\
\hline Extension & $6(14.63)$ & $12(35.29)$ & $2(12.50)$ & $0(0.00)$ & 20 \\
\hline Repairs/Renovation & $7(17.07)$ & $1(2.94)$ & $0(0.00)$ & $0(0.00)$ & 8 \\
\hline N & $41(100)$ & $34(100)$ & $16(100)$ & $9(100)$ & 100 \\
\hline
\end{tabular}

Chi-square value $=72.13$, d.f. $=12$, Significant at 1 per cent level of significance 
Income-wise, table 3 highlights that a major part of the respondents ( 88.89 per cent) from category I-4 and 75 per cent from category I-3 have taken the loan for the 'construction' of house. Further none of the respondents from both the categories I-3 and I-4 have taken the loan for 'purchase of plot' and 'repairs/renovation'. The Chisquare value (72.13) shows that there exists significant difference among different income categories as regards the purpose of loan.

Table 4 Purpose of Loan (Age-wise Distribution of Respondents)

\begin{tabular}{|c|c|c|c|c|c|}
\hline Purpose & A-1 & A-2 & A-3 & A-4 & TOTAL \\
\hline Purchase of Plot & $7(25.00)$ & $7(18.92)$ & $5(19.23)$ & $0(0.00)$ & 19 \\
\hline Purchase of House & $6(21.43)$ & $10(27.03)$ & $6(23.08)$ & $4(44.44)$ & 26 \\
\hline Construction & $4(14.29)$ & $9(24.32)$ & $9(34.62)$ & $5(55.56)$ & 27 \\
\hline Extension & $9(32.14)$ & $9(24.32)$ & $2(7.69)$ & $0(0.00)$ & 20 \\
\hline Repairs/Renovation & $2(7.14)$ & $2(5.41)$ & $4(15.38)$ & $0(0.00)$ & 8 \\
\hline N & $28(100)$ & $37(100)$ & $26(100)$ & $9(100)$ & 100 \\
\hline
\end{tabular}

Chi-square value $=17.79$, d.f. $=12$, Not Significant at 1 per cent level of significance

Age-wise, table 4 highlights that majority of the respondents (55.56 per cent) from category A-4 have taken loan for 'construction' of house. 44.44 per cent customers from A-4 and 27.03 per cent from category A-2 have taken loan for 'purchase of house' while 32.14 per cent from category A-1 have taken the loan for 'extension'. The Chi-square value (17.79) highlights significant relationship among different age categories regarding the purpose of loan.

\subsection{Amount of Loan}

The amount of loan varies from person to person according to their requirements, purpose of loan, income level and the repaying capacity. Tables 5 and 6 respectively present income-wise and age-wise distribution of the respondents with regard to the amount of loan.

Table 5 Amount of Loan (Income-wise Distribution of Respondents)

\begin{tabular}{|c|c|c|c|c|c|}
\hline Amount (in Rs.) & $\mathrm{I}-1$ & $\mathrm{I}-2$ & $\mathrm{I}-3$ & $\mathrm{I}-4$ & $\mathrm{~N}$ \\
\hline Below 5 lac & $7(17.07)$ & $3(8.82)$ & $0(0.00)$ & $0(0.00)$ & 10 \\
\hline 5-6 lac & $31(75.61)$ & $28(82.35)$ & $3(18.75)$ & $0(0.00)$ & 62 \\
\hline 6-8 lac & $2(4.88)$ & $3(8.82)$ & $11(68.75)$ & $2(22.22)$ & 18 \\
\hline Above 8 lac & $1(2.44)$ & $0(0.00)$ & $2(12.50)$ & $7(77.78)$ & 10 \\
\hline N & $41(100)$ & $34(100)$ & $16(100)$ & $9(100)$ & 100 \\
\hline
\end{tabular}

Chi-square value $=94.59$, d.f $=9$, Significant at 1 per cent level of significance

Income-wise, it is indicated in table 5 that 82.35 per cent respondents from category I-2 and 75.61 per cent respondents from category I-1 have taken loan amounting 'Rs. 5 lac to Rs. 6 lac'. Further none of the respondents from categories I-3 and I-4 have taken loan for the amount 'below Rs. 5 lac'. The Chi-square value (94.59) shows significant difference among different income categories with regard to amount of loan made by LIC Housing Finance Ltd.

Table 6 Amount of Loan (Age-wise Distribution of Respondents)

\begin{tabular}{|c|c|c|c|c|c|}
\hline Amount (in Rs.) & A-1 & A-2 & A-3 & A-4 & N \\
\hline Below 5 lac & $1(3.57)$ & $5(13.51)$ & $4(15.38)$ & $0(0.00)$ & 10 \\
\hline 5-6 lac & $22(78.57)$ & $25(67.57)$ & $12(46.15)$ & $3(33.33)$ & 62 \\
\hline 6-8 lac & $4(14.29)$ & $6(16.22)$ & $7(26.93)$ & $1(11.11)$ & 18 \\
\hline Above 8 lac & $1(3.57)$ & $1(2.70)$ & $3(11.54)$ & $5(55.56)$ & 10 \\
\hline N & $28(100)$ & $37(100)$ & $26(100)$ & $9(100)$ & 100 \\
\hline
\end{tabular}

Chi-square value $=30.47$, d.f. $=9$, Significant at 1 per cent level of significance

Age-wise, table 6 depicts that 78.57 per cent from category A-1 and 67.57 per cent from A-2 have taken loan amounting 'Rs. 5 lac to Rs. 6 lac' whereas 55.56 per cent from category A-4 have taken loans amounting 'Above Rs. 8 lac'. The Chi-square value (30.47) indicates significant differences among different age categories regarding the amount of loan. 


\subsection{Tenure of Loan}

The tenure of loan depends upon the customer's needs, purpose of loan and the repaying capacity of the borrower. Tables 7 and 8 respectively present income-wise and age-wise distribution of the respondents in this regard.

Table 7 Tenure of Loan (Income-wise Distribution of Respondents)

\begin{tabular}{|c|c|c|c|c|c|}
\hline Years & I-1 & I-2 & I-3 & I-4 & N \\
\hline Up to 10 & $7(17.07)$ & $2(5.88)$ & $0(0.00)$ & $0(0.00)$ & 9 \\
\hline $10-15$ & $15(36.59)$ & $17(50.00)$ & $6(37.50)$ & $1(11.11)$ & 39 \\
\hline $15-20$ & $19(46.34)$ & $12(35.29)$ & $8(50.00)$ & $8(88.89)$ & 47 \\
\hline Above 20 & $0(0.00)$ & $3(8.820$ & $2(12.50)$ & $0(0.00)$ & 5 \\
\hline $\mathrm{N}$ & $41(100)$ & $34(100)$ & $16(100)$ & $9(100)$ & 100 \\
\hline
\end{tabular}

Chi-square value $=20.61$, d.f. $=9$, Significant at 5 per cent level of significance

Income-wise, it is shown in table 7 that majority of the respondents (88.89 per cent) from category I-4 and 50 per cent from category I-3 have taken loan for the tenure of ' 15 to 20 years'. The Chi-square value (20.61) indicates significant differences among different income categories regarding the tenure of loan.

Table 8 Tenure of Loan (Age-wise Distribution of Respondents)

\begin{tabular}{|c|c|c|c|c|c|}
\hline Years & A-1 & A-2 & A-3 & A-4 & N \\
\hline Up to 10 & $0(0.00)$ & $3(8.11)$ & $6(23.08)$ & $3(33.33)$ & 9 \\
\hline $10-15$ & $14(50.00)$ & $19(51.34)$ & $6(23.08)$ & $0(0.00)$ & 39 \\
\hline $15-20$ & $14(50.00)$ & $16(43.24)$ & $11(42.31)$ & $6(66.67)$ & 47 \\
\hline Above 20 & $0(0.00)$ & $2(5.41)$ & $3(11.53)$ & $0(0.00)$ & 5 \\
\hline $\mathrm{N}$ & $28(100)$ & $37(100)$ & $26(100)$ & $9(100)$ & 100 \\
\hline
\end{tabular}

Chi-square value $=37.95$, d.f. $=9$, Significant at 1 per cent level of significance

Age-wise, table 8 shows that 66.67 per cent from A-4 have taken loan for ' 15 to 20 years' whereas 51.34 per cent from A-2 and 50 per cent from A-1 have taken loan for the tenure of ' 10 to 15 years'. The Chisquare value (37.95) is greater than the table value (21.7) at 1 per cent level of significance depicting that there exists significant difference among different age groups regarding the tenure of loan.

\subsection{Time to Sanction Loan}

Every institution takes a few days to process the application of the customer and sanction the loan.

Table 9 Time to Sanction Loan (Income-wise Distribution of Respondents)

\begin{tabular}{|c|c|c|c|c|c|}
\hline Days & I-1 & I-2 & I-3 & I-4 & N \\
\hline Below 15 & $4(9.75)$ & $3(8.82)$ & $1(6.25)$ & $0(0.00)$ & 8 \\
\hline $15-30$ & $16(39.02)$ & $13(38.24)$ & $10(62.50)$ & $6(66.67)$ & 45 \\
\hline $30-45$ & $11(26.82)$ & $17(50.00)$ & $5(31.25)$ & $3(33.33)$ & 43 \\
\hline Above 45 & $3(7.32)$ & $1(2.94)$ & $0(0.00)$ & $0(0.00)$ & 4 \\
\hline N & $41(100)$ & $34(100)$ & $16(100)$ & $9(100)$ & 100 \\
\hline
\end{tabular}

Chi-square value $=13.32$, d.f. $=9$, Not Significant at 5 per cent level of significance

Income-wise, table 9 shows that 66.67 per cent from I-4 and 62.50 per cent from I-3 have got the loan sanctioned between 15 to 30 days. Further 39.02 per cent of the respondents from category I-1 have taken loan for the period of ' 15 to 30 days', followed by '30 to 45 days' (26.82 per cent), 'below 15 days' (9.75 per cent) and 'above 45 days' (7.32 per cent). The Chi-square value (13.32) is less than table value (16.9) at 5 per cent level of significance that shows significant relationship among different income groups regarding the time taken to sanction the loan.

Table 10 Time to Sanction Loan (Age-wise Distribution of Respondents)

\begin{tabular}{|c|c|c|c|c|c|}
\hline Days & A-1 & A-2 & A-3 & A-4 & $\mathrm{N}$ \\
\hline Below 15 & $4(14.29)$ & $4(10.81)$ & $0(0.00)$ & $0(0.00)$ & 8 \\
\hline $15-30$ & $7(25.00)$ & $13(35.14)$ & $19(73.08)$ & $6(66.67)$ & 45 \\
\hline $30-45$ & $16(57.14)$ & $18(48.65)$ & $6(23.08)$ & $3(33.33)$ & 43 \\
\hline Above 45 & $1(3.57)$ & $2(5.40)$ & $1(3.84)$ & $0(0.00)$ & 4 \\
\hline $\mathrm{N}$ & $28(100)$ & $37(100)$ & $26(100)$ & $9(100)$ & 100 \\
\hline
\end{tabular}

Chi-square value $=22.16$, d.f. $=9$, Significant at 1 per cent level of significance 
Age-wise, table 10 shows that majority of the respondents (73.08 per cent) from category A-3 and 66.67 per cent from category A-4 have got the loan sanctioned between ' 15 to 30 days'. The Chi-square value (22.16) is greater than table value (21.7) at 1 per cent level of significance showing that there exists significant difference among different age categories as far as the time taken to sanction loan is concerned.

\subsection{Number of Times the Beneficiaries Have Visited the Institution}

The customers have to visit the institution a number of times to get the sanction of loan after submission of their applications. The company verifies various documents required for the sanction of loan.

Table 11 Number of Visits of the Beneficiaries to the Institution (Income-wise Distribution of Respondents)

\begin{tabular}{|c|c|c|c|c|c|}
\hline No. of times & $\mathrm{I}-1$ & $\mathrm{I}-2$ & $\mathrm{I}-3$ & $\mathrm{I}-4$ & TOTAL \\
\hline Less than 5 & $21(51.22)$ & $21(61.76)$ & $6(37.50)$ & $0(0.00)$ & 48 \\
\hline $5-10$ & $2(4.88)$ & $1(2.94)$ & $4(25.00)$ & $2(22.22)$ & 9 \\
\hline $10-15$ & $14(34.15)$ & $9(26.47)$ & $3(18.75)$ & $6(66.67)$ & 32 \\
\hline more than 15 & $4(9.75)$ & $3(8.82)$ & $3(18.75)$ & $1(11.11)$ & 11 \\
\hline $\mathrm{N}$ & $41(100)$ & $34(100)$ & $16(100)$ & $9(100)$ & 100 \\
\hline
\end{tabular}

Chi-square value $=20.22$, d.f. $=9$, Significant at 5 per cent level of significance

Income-wise, table 11 depicts that majority of the respondents ( 66.67 per cent) from I-4 have visited the institution for ' 10 to 15 times' whereas 61.76 per cent from category I-2, 51.22 per cent from category I-1 and 37.50 per cent from category I-3 have to visit 'less than 5 times'. The Chi-square value (20.22) is higher than the table value (16.9) at 5 per cent level of significance showing that significant differences exist among different income categories regarding the times to visit the institution for the sanction of loan.

Table 12 Number of Visits of the Beneficiaries to the Institution (Age-wise Distribution of Respondents)

\begin{tabular}{|c|c|c|c|c|c|}
\hline No. of times & A-1 & A-2 & A-3 & A-4 & TOTAL \\
\hline Less than 5 & $25(89.29)$ & $20(54.05)$ & $3(11.54)$ & $0(0.00)$ & 48 \\
\hline $5-10$ & $1(3.57)$ & $2(5.41)$ & $5(19.23)$ & $1(11.11)$ & 9 \\
\hline $10-15$ & $2(7.14)$ & $9(24.32)$ & $13(50.00)$ & $8(88.89)$ & 32 \\
\hline more than 15 & $0(0.00)$ & $6(16.21)$ & $5(19.23)$ & $0(0.00)$ & 11 \\
\hline N & $28(100)$ & $37(100)$ & $26(100)$ & $9(100)$ & 100 \\
\hline
\end{tabular}

Chi-square value $=50.56$, d.f. $=9$, Significant at 1 per cent level of significance

Age-wise, table 12 shows that majority of the respondents from category A-1 (89.29 per cent) and A-2 ( 54.05 per cent) have to visit the institution 'less than 5 times' whereas 88.89 per cent from category A- 4 and 50 per cent from category A-3 have to visit the institution for ' 10 to 15 times'. The Chi-square value (50.66) is higher than the table value (21.7) at 1 per cent level of significance showing that significant differences exist among different age categories regarding the times to visit the institution to get the sanction of loan.

\subsection{Reason of Delay}

In a query from the respondents 64 per cent of the respondents have complained regarding the delay in the sanctioning and disbursement of loan. The reasons put by them for such delays were unnecessary queries, excessive documentation and others including callous attitude of the staff, staff paucity, etc. Further no significant differences were observed as regards reason of delay among different income categories and age groups of the respondents.

\subsection{Number of Times Officials Visited the Site Prior To Sanction Of Loan}

The officials of the company visit the site of the borrower for which the loan has been applied for. So the customers were asked about the number of times the officials had visited the site prior to the sanction of loan. 
Table 13 Number of Visits of the Officials to the Site (Income-wise Distribution of Respondents)

\begin{tabular}{|c|c|c|c|c|c|}
\hline No. of times & I-1 & I-2 & I-3 & I-4 & TOTAL \\
\hline Once & $15(36.59)$ & $10(29.41)$ & $2(12.50)$ & $0(0.00)$ & 27 \\
\hline Twice & $6(14.63)$ & $13(38.24)$ & $3(18.75)$ & $0(0.00)$ & 22 \\
\hline Thrice or more & $20(48.78)$ & $11(32.35)$ & $11(68.75)$ & $9(100.00)$ & 51 \\
\hline N & $41(100)$ & $34(100)$ & $16(100)$ & $9(100)$ & 100 \\
\hline
\end{tabular}

Chi-square value $=19.85$, d.f. $=6$, Significant at 5 per cent level of significance

Income-wise, table 13 depicts that all the respondents from the category I-4, a large proportion of the respondents from category I-3 (68.75 per cent) and I-1 (48.78 per cent) have answered that officials visited 'thrice or more'. The Chi-square value (19.85) is higher than the table value (12.6 per cent) at 5 per cent level of significance showing that significant differences exist among different income categories regarding the number of times officials visited the site prior to the sanction of loan.

Table 14 Number of Visits of the Officials to the Site (Age-wise Distribution of Respondents)

\begin{tabular}{|c|c|c|c|c|c|}
\hline No. of times & A-1 & A-2 & A-3 & A-4 & TOTAL \\
\hline Once & $14(50.00)$ & $11(29.73)$ & $2(7.69)$ & $0(0.00)$ & 27 \\
\hline Twice & $11(39.29)$ & $10(27.03)$ & $1(4.35)$ & $0(0.00)$ & 22 \\
\hline Thrice or more & $3(10.71)$ & $16(43.24)$ & $23(88.46)$ & $9(100.00)$ & 51 \\
\hline N & $28(100)$ & $37(100)$ & $26(100)$ & $9(100)$ & 100 \\
\hline
\end{tabular}

Chi-square value $=42.44$ d.f. $=6$, Significant at 1 per cent level of significance

Age-wise, table 14 shows that all the respondents from category A-4 and 88.46 per cent from category A-3 have responded that officials visited the site 'thrice or more' whereas 50 per cent from the category A-1 have responded that officials visited 'once'. The Chi-square value (42.44) is higher than the table value (12.6) at 5 per cent level of significance highlighting that there exists significant difference among different age groups as regards the number of times the officials visited the site prior to sanction of loan.

\subsection{Rate of Interest}

LICHFL has charged the floating rate of interest from all the respondents. The floating rate changes with the prevailing conditions in the market. Majority of the respondents ( 56 per cent) have been charged interest rate of ' 10 per cent and above' followed by those who have been charged interest rate 'below 10 per cent' (20 per cent) in the first half year.

\subsection{Cost of Loan}

The borrowers have to incur some cost in order to avail loans from HFCs. This cost includes processing fees, administration fees, stamp duties and other charges. Tables 15 and 16 respectively present income-wise and age-wise distribution of respondents with regard to cost of loan.

Table 15 Cost of Loan (Income-wise Distribution of Respondents)

\begin{tabular}{|l|c|c|c|c|c|}
\hline Cost (in Rs.) & I-1 & I-2 & I-3 & I-4 & TOTAL \\
\hline Below 8500 & $10(24.39)$ & $14(41.18)$ & $2(12.50)$ & $0(0.00)$ & 26 \\
\hline $8500-9500$ & $21(51.22)$ & $13(38.24)$ & $3(18.75)$ & $1(11.11)$ & 38 \\
\hline $9500-10500$ & $7(17.07)$ & $5(14.71)$ & $5(31.25)$ & $2(22.22)$ & 19 \\
\hline Above 10500 & $3(7.32)$ & $2(5.88)$ & $6(37.50)$ & $6(66.67)$ & 17 \\
\hline N & $41(100)$ & $34(100)$ & $16(100)$ & $9(100)$ & 100 \\
\hline
\end{tabular}

Chi-square value $=35.14$, d.f. $=9$, Significant at 1 per cent level of significance

Income-wise, table 15 shows that 66.67 per cent from category I-4 have incurred the cost of loan 'above Rs. 10500' whereas 51.22 per cent from category I-1 have incurred the cost between 'Rs. 8500 - Rs. 9500'. The Chi-square value (35.14) is higher than table value (12.7) at 1 per cent level of significance depicting the significant difference among different income groups as regards the cost of loan. 
Table 16 Cost of Loan (Age-wise Distribution of Respondents)

\begin{tabular}{|l|c|c|c|c|c|}
\hline Cost (in Rs.) & A-1 & A-2 & A-3 & A-4 & TOTAL \\
\hline Below 8500 & $13(46.43)$ & $9(24.32)$ & $4(15.38)$ & $0(0.00)$ & 26 \\
\hline $8500-9500$ & $9(32.14)$ & $20(54.05)$ & $8(30.77)$ & $1(11.11)$ & 38 \\
\hline $9500-10500$ & $5(17.86)$ & $5(13.51)$ & $6(23.08)$ & $3(33.33)$ & 19 \\
\hline Above 10500 & $1(3.57)$ & $3(8.12)$ & $8(30.77)$ & $5(55.56)$ & 17 \\
\hline N & $28(100)$ & $37(100)$ & $26(100)$ & $9(100)$ & 100 \\
\hline
\end{tabular}

Chi-square value $=30.1$, d.f. $=9$, Significant at 1 per cent level of significance

Age-wise, it is depicted in table 16 that major part of the respondents (55.56 per cent) from A-4 and 30.77 per cent from category A-3 have incurred the cost of loan 'above Rs. 10500'. The Chi-square value (30.11) is more than table value (21.7) at 1 per cent level of significance that means significant difference exists among different age groups regarding the cost of loan.

\subsection{Repayment Schedule of Loan}

In order to effectively reach and help more and more people, timely recovery of loans is of utmost importance. This facilitates recycling of the funds to other expected borrowers. The customers were asked about the repayment schedule of their loans. It was observed that all the respondents were repaying the loan through Equated Monthly Instalments.

\subsection{Respondent's Opinion Regarding Various Factors}

The customers were asked to show their satisfaction level on a five-point scale in order to ascertain their satisfaction level regarding various factors like processing time of loan, tenure of loan, security for loan, etc. Table 17 shows the frequency distribution of the responses of the respondents in this regard.

Table 17 Respondent's Satisfaction Level Regarding Various factors

\begin{tabular}{|l|c|c|c|c|c|c|}
\hline \multicolumn{1}{|c|}{ Factor } & $\begin{array}{c}\text { Highly } \\
\text { Satisfie } \\
\mathrm{d}\end{array}$ & $\begin{array}{c}\text { Satisfie } \\
\mathrm{d}\end{array}$ & $\begin{array}{c}\text { Neither } \\
\text { Satisfied } \\
\text { Nor } \\
\text { Dissatisfied }\end{array}$ & $\begin{array}{c}\text { Dissatis } \\
\text { fied }\end{array}$ & $\begin{array}{c}\text { Highly } \\
\text { Dissati } \\
\text { sfied }\end{array}$ & $\begin{array}{c}\text { Average } \\
\text { Weighted } \\
\text { Scores }\end{array}$ \\
\hline $\begin{array}{l}\text { Processing time of } \\
\text { loan }\end{array}$ & 5 & 41 & 25 & 14 & 15 & 0.07 \\
\hline Tenure of loan & 4 & 56 & 32 & 7 & 1 & 0.55 \\
\hline Security Requirement & 3 & 55 & 26 & 12 & 4 & 0.41 \\
\hline Repayment Schedule & 3 & 56 & 29 & 7 & 5 & 0.45 \\
\hline Rate of Interest & 3 & 46 & 37 & 11 & 3 & 0.35 \\
\hline Adequacy of loan & 2 & 66 & 15 & 14 & 3 & 0.50 \\
\hline Knowledge of Staff & 4 & 63 & 25 & 8 & 0 & 0.63 \\
\hline Attentiveness of Staff & 4 & 68 & 19 & 9 & 0 & 0.67 \\
\hline Efficiency of Staff & 5 & 66 & 18 & 11 & 0 & 0.65 \\
\hline Co-operation of Staff & 6 & 65 & 19 & 9 & 1 & 0.66 \\
\hline Behaviour of Staff & 6 & 67 & 17 & 9 & 1 & 0.68 \\
\hline Loan Procedure & 5 & 46 & 29 & 8 & 12 & 0.14 \\
\hline Grievance Handling & 6 & 58 & 30 & 4 & 2 & 0.62 \\
\hline
\end{tabular}

The table 17 depicts that majority of the respondents have expressed their satisfaction with regard to behaviour of staff ( 73 per cent), attentiveness of staff ( 72 per cent), efficiency of staff ( 71 per cent), co-operation of staff (71 per cent), adequacy of loan (68 per cent), knowledge of staff (67 per cent), grievance handling (64 per cent). However many of the respondents have expressed their dissatisfaction regarding processing time of loan (29 per cent), loan procedure (20 per cent), etc.

To analyze, average weighted scores have been calculated. The scale range has been taken from +2 to 2 by assigning +2 for the 'highly satisfied', +1 for 'satisfied', 0 for 'neither satisfied nor dissatisfied', -1 for the 'dissatisfied' and -2 for 'highly dissatisfied'. Tables 20 and 21 respectively present the income-wise and agewise average weighted scores in this regard. 
Table 18 AWS corresponding to Satisfaction Level of Respondents (Income-wise Distribution)

\begin{tabular}{|l|c|c|c|c|c|}
\hline Factor & I-1 & I-2 & I-3 & I-4 & Total \\
\hline Processing time of loan & 0.05 & 0.18 & 0.06 & -0.22 & 0.07 \\
\hline Tenure of loan & 0.51 & 0.59 & 0.63 & 0.44 & 0.55 \\
\hline Security Requirement & 0.39 & 0.35 & 0.63 & 0.33 & 0.41 \\
\hline Repayment Schedule & 0.39 & 0.56 & 0.43 & 0.56 & 0.45 \\
\hline Rate of Interest & 0.22 & 0.44 & 0.38 & 0.56 & 0.35 \\
\hline Adequacy of loan & 0.41 & 0.44 & 0.81 & 0.78 & 0.50 \\
\hline Knowledge of Staff & 0.59 & 0.62 & 0.75 & 0.89 & 0.63 \\
\hline Attentiveness of Staff & 0.59 & 0.76 & 0.81 & 0.44 & 0.67 \\
\hline Efficiency of Staff & 0.56 & 0.73 & 0.81 & 0.67 & 0.65 \\
\hline Co-operation of Staff & 0.59 & 0.68 & 0.81 & 0.67 & 0.66 \\
\hline Behaviour of Staff & 0.59 & 0.73 & 0.81 & 0.67 & 0.68 \\
\hline Loan Procedure & 0.22 & 0.26 & 0.25 & 0.22 & 0.14 \\
\hline Grievance Handling & 0.51 & 0.65 & 0.81 & 0.67 & 0.62 \\
\hline Mean Value of AWS & 0.43 & 0.54 & 0.61 & 0.51 & 0.49 \\
\hline
\end{tabular}

Income-wise, table 18 depicts that the respondents are satisfied with regard to knowledge of staff, efficiency of staff, co-operation of staff, behaviour of staff and grievance handling in all the four income levels. The respondents are less satisfied as regards processing time of loan and in case of I-4 they are dissatisfied (0.22). The satisfaction level is very low in case of rate of interest. The respondents are very less satisfied with regard to loan procedure in all the four income levels. The mean value of Average Weighted Scores corresponding to the satisfaction level of respondents regarding various factors is the highest in I-3 (0.61) followed by I-2 (0.54), I-4 (0.51) and I-1 (0.43).

Table 19 AWS corresponding to Satisfaction Level of Respondents (Age-wise Distribution)

\begin{tabular}{|l|c|c|c|c|c|}
\hline Factor & $\mathrm{A}-1$ & $\mathrm{~A}-2$ & $\mathrm{~A}-3$ & $\mathrm{~A}-4$ & Total \\
\hline Processing time of loan & 0.46 & 0.03 & 0.15 & 0.11 & 0.07 \\
\hline Tenure of loan & 0.86 & 0.49 & 0.31 & 0.56 & 0.55 \\
\hline Security Requirement & 0.68 & 0.32 & 0.19 & 0.56 & 0.41 \\
\hline Repayment Schedule & 0.89 & 0.27 & 0.15 & 0.67 & 0.45 \\
\hline Rate of Interest & 0.75 & 0.11 & 0.27 & 0.33 & 0.35 \\
\hline Adequacy of loan & 0.86 & 0.03 & 0.35 & 0.89 & 0.50 \\
\hline Knowledge of Staff & 0.68 & 0.51 & 0.69 & 0.78 & 0.63 \\
\hline Attentiveness of Staff & 0.68 & 0.57 & 0.77 & 0.78 & 0.67 \\
\hline Efficiency of Staff & 0.64 & 0.57 & 0.65 & 0.78 & 0.65 \\
\hline Co-operation of Staff & 0.79 & 0.51 & 0.69 & 0.78 & 0.66 \\
\hline Behaviour of Staff & 0.79 & 0.51 & 0.73 & 0.89 & 0.68 \\
\hline Loan Procedure & 0.50 & 0.19 & 0.00 & 0.33 & 0.14 \\
\hline Grievance Handling & 0.93 & 0.51 & 0.46 & 0.56 & 0.62 \\
\hline Mean Value of AWS & 0.73 & 0.36 & 0.42 & 0.62 & 0.49 \\
\hline
\end{tabular}

Age-wise, table 19 shows that respondents are satisfied with regard to knowledge, behaviour, attentiveness, co-operation, efficiency of staff and grievance handling in all the four age groups. The respondents are indifferent or satisfaction level is low regarding processing time of loan. The customers are indifferent or very less satisfied with regard to loan procedure in all the four age groups. The mean value of Average Weighted Scores corresponding to the satisfaction level of respondents regarding various factors is the highest in A-1 (0.73) followed by A-4 (0.62), A-3 (0.42) and A-2 (0.36).

\subsection{Respondent's Opinion Regarding Various Opinion Statements}

Customers were asked to give their views on a five-point scale regarding various statements. Table 20 shows the frequency distribution of the respondents in this regard. 
Table 20 Distribution of the Respondent's Consent Regarding Various Opinion Statements

\begin{tabular}{|l|c|c|c|c|c|c|}
\hline Statement & $\begin{array}{c}\text { Strongly } \\
\text { Agree }\end{array}$ & Agree & $\begin{array}{c}\text { Neither } \\
\text { Agree Nor } \\
\text { Disagree }\end{array}$ & Disagree & $\begin{array}{c}\text { Strongly } \\
\text { Disagree }\end{array}$ & $\begin{array}{c}\text { Average } \\
\text { Weighted } \\
\text { Scores }\end{array}$ \\
\hline $\begin{array}{l}\text { Procedural formalities } \\
\text { involved in processing } \\
\text { of loan are reasonable. }\end{array}$ & 10 & 40 & 22 & 13 & 15 & 0.17 \\
\hline $\begin{array}{l}\text { EMIs are reasonable } \\
\text { and convenient. }\end{array}$ & 10 & 51 & 23 & 14 & 2 & 0.53 \\
\hline $\begin{array}{l}\text { LICHFL charges } \\
\text { interest rate lower } \\
\text { than other institutions. }\end{array}$ & 12 & 38 & 42 & 7 & 1 & 0.53 \\
\hline $\begin{array}{l}\text { Having availed a } \\
\text { housing loan you are } \\
\text { able to reduce tax } \\
\text { liability. }\end{array}$ & 12 & 50 & 37 & 1 & 0 & 0.73 \\
\hline
\end{tabular}

Table 20 shows that majority of the respondents (62 per cent) have shown their satisfaction regarding the statement 'Having availed a housing loan you are able to reduce tax liability', 'EMIs are reasonable and convenient' (61 per cent), 'LICHFL charges interest on loan lower than other institutions' (50 per cent) and 'Procedural formalities involved in processing/sanctioning and disbursing of loan are reasonable' (50 per cent). The tables 21 and 22 respectively show the Average Weighted Scores in this regard.

Table 21 AWS corresponding to Degree of Consent of Respondents (Income-wise Distribution)

\begin{tabular}{|l|c|c|c|c|c|}
\hline Statement I-1 & $\mathrm{I}-2$ & $\mathrm{I}-3$ & $\mathrm{I}-4$ & Total \\
\hline $\begin{array}{l}\text { Procedural formalities involved in } \\
\text { processing/ sanctioning and disbursing } \\
\text { of loan are reasonable. }\end{array}$ & 0.02 & 0.35 & 0.19 & 0.11 & 0.17 \\
\hline EMIs are reasonable and convenient. & 0.32 & 0.62 & 0.69 & 0.89 & 0.53 \\
\hline $\begin{array}{l}\text { LICHFL charges interest rate lower } \\
\text { than other institutions. }\end{array}$ & 0.44 & 0.79 & 0.31 & 0.33 & 0.53 \\
\hline $\begin{array}{l}\text { Having availed a housing loan you are } \\
\text { able to reduce tax liability. }\end{array}$ & 0.37 & 1.00 & 1.06 & 0.78 & 0.75 \\
\hline Mean Value of AWS & 0.29 & 0.69 & 0.56 & 0.53 & 0.49 \\
\hline
\end{tabular}

Income-wise, table 21 depicts that respondents are highly satisfied with regard to the statement 'Having availed a housing loan you are able to reduce tax liability' in all income levels except in I-4 (0.78) in which they are satisfied and I-1 (0.37) the satisfaction level is low. Regarding the statement 'Procedural formalities involved in processing/sanctioning and disbursing of loan are reasonable' the respondents are indifferent or the satisfaction level is very low. The mean value of Average Weighted Scores corresponding to the satisfaction level of respondents regarding various statements is the highest in I-2 (0.69), I-3 (0.56), I-4 (0.53) and I-1 (0.29).

Table 22 AWS corresponding to Degree of Consent of Respondents

(Age-wise Distribution)

\begin{tabular}{|l|c|c|c|c|c|}
\hline \multicolumn{1}{|c|}{ Statement A-1 } & $\mathrm{A}-2$ & $\mathrm{~A}-3$ & $\mathrm{~A}-4$ & Total \\
\hline $\begin{array}{l}\text { Procedural formalities involved in } \\
\text { processing/ sanctioning and disbursing of } \\
\text { loan are reasonable. }\end{array}$ & 0.54 & 0.11 & -0.15 & 0.22 & 0.17 \\
\hline EMIs are reasonable and convenient. & 0.93 & 0.24 & 0.46 & 0.67 & 0.53 \\
\hline $\begin{array}{l}\text { LICHFL charges interest rate lower than } \\
\text { other institutions. }\end{array}$ & 0.93 & 0.46 & 0.27 & 0.33 & 0.53 \\
\hline $\begin{array}{l}\text { Having availed a housing loan you are } \\
\text { able to reduce tax liability. }\end{array}$ & 1.04 & 0.73 & 0.46 & 0.56 & 0.73 \\
\hline Mean Value of AWS & 0.86 & 0.39 & 0.26 & 0.45 & 0.49 \\
\hline
\end{tabular}


Age-wise, table 22 highlights that respondents are highly satisfied with regard to 'Having availed a housing loan you are able to reduce tax liability' in category A-1 and in all other categories they are satisfied. The mean value of Average Weighted Scores corresponding to the satisfaction level of respondents regarding various statements is the highest in A-1 (0.86), A-4 (0.45), A-2 (0.39) and A-3 (0.26).

\subsection{Overall Satisfaction Level}

The respondents were asked to mention their opinion regarding the overall satisfaction level about the institution. Tables 23 and 24 respectively present the income-wise and age-wise distribution of respondents in this regard

Table 23 Overall Satisfaction Level (Income-wise Distribution of Respondents)

\begin{tabular}{|l|c|c|c|c|c|}
\hline Scale & $\mathrm{I}-1$ & $\mathrm{I}-2$ & $\mathrm{I}-3$ & $\mathrm{I}-4$ & Total \\
\hline Highly Satisfied & $2(4.88)$ & $4(11.76)$ & $0(0.00)$ & $0(0.00)$ & 6 \\
\hline Satisfied Satisfied Nor & $28(68.29)$ & $21(61.76)$ & $12(75.00)$ & $5(55.56)$ & 66 \\
\hline $\begin{array}{l}\text { Neither } \\
\text { Dissatisfied }\end{array}$ & $6(14.63)$ & $7(20.59)$ & $4(25.00)$ & $2(22.22)$ & 19 \\
\hline Dissatisfied Average & $4(9.76)$ & $2(5.88)$ & $0(0.00)$ & $2(22.22)$ & 8 \\
\hline Highly Dissatisfied & $1(2.44)$ & $0(0.00)$ & $0(0.00)$ & $0(0.00)$ & 1 \\
\hline N & $41(100)$ & $34(100)$ & $16(100)$ & $9(100)$ & 100 \\
\hline $\begin{array}{l}\text { Weighted } \\
\text { Scores }\end{array}$ & 0.63 & 0.75 & 0.33 & 0.68 \\
\hline
\end{tabular}

Table 23 depicts that proportionately more respondents (75 per cent) from I-3 followed by 68.29 per cent from category I-1, 61.76 per cent from I-2 and 55.56 per cent from I-4 are satisfied with the institution. The Weighted Average Scores reveal that the respondents are satisfied in all the income categories except I-4 in which the satisfaction level is low (0.33) with regards to the overall satisfaction about the institution.

Table 24 Overall Satisfaction Level (Age-wise Distribution of Respondents)

\begin{tabular}{|c|c|c|c|c|c|}
\hline Scale & A-1 & A-2 & A-3 & A-4 & Total \\
\hline Highly Satisfied & $2(7.14)$ & $4(10.81)$ & $0(0.00)$ & $0(0.00)$ & 6 \\
\hline Satisfied & $23(82.14)$ & $21(56.76)$ & $16(61.54)$ & $6(66.67)$ & 66 \\
\hline $\begin{array}{l}\text { Neither Satisfied Nor } \\
\text { Dissatisfied }\end{array}$ & $3(10.71)$ & $8(21.62)$ & $6(23.08)$ & $2(22.22)$ & 19 \\
\hline Dissatisfied & $0(0.00)$ & $3(8.11)$ & $4(15.38)$ & $1(11.11)$ & 8 \\
\hline Highly Dissatisfied & $0(0.00)$ & $1(2.70)$ & $0(0.00)$ & $0(0.00)$ & 1 \\
\hline $\mathrm{N}$ & $28(100)$ & $37(100)$ & $26(100)$ & $9(100)$ & 100 \\
\hline $\begin{array}{l}\text { Weighted Average } \\
\text { Scores }\end{array}$ & 0.96 & 0.65 & 0.46 & 0.56 & 0.68 \\
\hline
\end{tabular}

Age wise, in table 24 the Weighted Average Scores show that the respondents are satisfied with the institution in all age categories except in A-3 where the satisfaction level is low (0.46).

\subsection{Opinion Regarding the Decision to Take Loan In Future}

The respondents were asked regarding their decision to take loan from LIC Housing Finance Ltd in future or not. Tables 25 and 26 respectively present the income-wise and age-wise distribution of respondents in this regard.

Table 25 Decision to Take Loan in Future (Income-wise Distribution of Respondents)

\begin{tabular}{|c|c|c|c|c|c|}
\hline Response & $\mathrm{I}-1$ & $\mathrm{I}-2$ & $\mathrm{I}-3$ & $\mathrm{I}-4$ & $\mathrm{~N}$ \\
\hline Yes & $31(75.61)$ & $29(85.29)$ & $12(75.00)$ & $5(55.56)$ & 77 \\
\hline No & $9(21.95)$ & $2(5.88)$ & $3(18.75)$ & $2(22.22)$ & 16 \\
\hline Will see & $1(2.44)$ & $3(8.82)$ & $1(6.25)$ & $2(22.22)$ & 9 \\
\hline N & $41(100)$ & $34(100)$ & $16(100)$ & $9(100)$ & 100 \\
\hline
\end{tabular}

Chi-square value $=8.62$, d.f. $=6$, Not Significant at 5 per cent level of significance

Income wise, it is highlighted in table 25 that 85.29 per cent from category I- 2 followed by 75.61 per cent from category I-1, 75 per cent from category I-3 and 55.56 per cent from category I-4 have decided to take 
loan from LICHFL in future. The Chi-square value (8.62) shows significant relationship among different income categories regarding the decision to take loan from LICHFL in future.

Table 26 Decision to Take Loan in Future

(Age-wise Distribution of Respondents)

\begin{tabular}{|c|c|c|c|c|c|}
\hline Response & A-1 & A-2 & A-3 & A-4 & N \\
\hline Yes & $25(89.29)$ & $28(75.68)$ & $18(69.23)$ & $6(66.67)$ & 77 \\
\hline No & $3(10.71)$ & $7(18.92)$ & $5(19.23)$ & $1(11.11)$ & 16 \\
\hline Will see & $0(0.00)$ & $2(5.40)$ & $3(11.54)$ & $2(22.22)$ & 7 \\
\hline N & $28(100)$ & $37(100)$ & $26(100)$ & $9(100)$ & 100 \\
\hline
\end{tabular}

Chi-square value $=7.71$, d.f. $=6$, Not Significant at 5 per cent level of significance

Age-wise, table 26 shows the non-existence of significant difference among different age categories as regards the decision to take loan from LICHFL in future.

\section{Conclusion And Suggestions}

The respondents from all the occupational categories are far less satisfied with regard to processing time of loan and the loan procedure. The respondents were of the view that they have to visit the institution many times to get their loans sanctioned and disbursed which results in wastage of their time in this process. Furthermore, majority of the respondents have expressed their satisfaction regarding the performance of the company. Majority of the respondents (77 per cent) are likely to take loan from LICHFL in future followed by those who have decided not to take loan from the company in future (16 per cent) and those who will decide depending upon the situation ( 7 per cent). The customers are dissatisfied regarding the processing time of loan and the loan procedure of the company. Therefore, the company should make prompt loan sanctions and the loan procedure need to be simplified in order to avoid the wastage of time of the borrowers. The company must sanction the loan in the minimum possible time to satisfy the customers and this should be adopted as a marketing tool to compete with other institutions. It has also been observed the number of female respondents was just 27 out of the total respondents surveyed. This indicates wide disproportions of housing loan allocation. Further, there is no scheme of LICHFL which specifically cater to the housing needs of women. Therefore, to bring gender-wise equality in home ownership and to encourage women in availing housing loan on their own name, the company should develop special products for this category. This will help in increasing the market share of the company and is also socially desirable.

\section{References}

[1] Annual Reports of LICHFL for the year 2003-04 to 2011-12

[2] Gupta, S.P. "Statistical Methods", Sultan Chand and Sons Educational Publishers, New Delhi (2002), pp. 953-1002. 